\title{
A DEFECTIVE MUTANT OF Salmonella enterica Serovar Gallinarum IN COBALAMIN BIOSYNTHESIS IS
} AVIRULENT IN CHICKENS

\author{
Jacqueline Boldrin de Paiva ${ }^{1}$, Rafael Antonio Casarin Penha Filho ${ }^{1}$, Yuli Melisa Sierra Arguello ${ }^{1}$, Ângelo Berchieri \\ Junior $^{1 *}$, Manuel Victor Franco Lemos ${ }^{1}$, Paul A. Barrow ${ }^{2}$ \\ ${ }^{1}$ Faculdade de Ciências Agrárias e Veterinárias, Universidade Estadual Paulista, Jaboticabal, SP, Brasil; ${ }^{2}$ School of Veterinary \\ Medicine and Science, University of Nottingham, Sutton Bonington, Loughborough LE12 5RD, UK
}

Submitted: January 14, 2009; Returned to authors for corrections: February 11, 2009; Approved: May 03, 2009.

\begin{abstract}
Salmonella enterica serovar Gallinarum (SG) is a fowl typhoid agent in chickens and is a severe disease with worldwide economic impact as its mortality may reach up to $80 \%$. It is one of a small group of serovars that typically produces typhoid-like infections in a narrow range of host species and which therefore represents a good model for human typhoid. The survival mechanisms are not considered to be virulent mechanisms but are essential for the life of the bacterium. Mutants of Salmonella Gallinarum containing defective genes, related to cobalamin biosynthesis and which Salmonella spp. has to be produced to survive when it is in an anaerobic environment, were produced in this study. Salmonella Gallinarum is an intracellular parasite. Therefore, this study could provide information about whether vitamin $\mathrm{B}_{12}$ biosynthesis might be essential to its survival in the host. The results showed that the singular deletion in $c b i \mathrm{~A}$ or $c o b \mathrm{~S}$ genes did not interfere in the life of Salmonella Gallinarum in the host, perhaps because single deletion is not enough to impede vitamin $\mathrm{B}_{12}$ biosynthesis. It was noticed that diluted SG mutants with single deletion produced higher mortality than the wild strain of SG. When double mutation was carried out, the Salmonella Gallinarum mutant was unable to provoke mortality in susceptible chickens. This work showed that $\mathrm{B}_{12}$ biosynthesis is a very important step in the metabolism of Salmonella Gallinarum during the infection of the chickens. Further research on bacterium physiology should be carried out to elucidate the events described in this research and to assess the mutant as a vaccine strain.
\end{abstract}

Key words: Salmonella Gallinarum, cobalamin biosynthesis, attenuated strain, $c b i \mathrm{~A}$ and $c o b \mathrm{~S}$ genes

\footnotetext{
*Corresponding Author. Mailing address: Faculdade de Ciências Agrárias e Veterinárias, Universidade Estadual Paulista - FCAV-Unesp, Via Paulo Donato Castellane s/n. 14884-900, Jaboticabal-SP, Brazil tel: 0055 3209- 2663; fax: 0055 3209-2859; e-mail: berchier@,fcav.unesp.br
} 
Paiva, J.B. et al.

\section{INTRODUCTION}

Salmonella enterica serovar Gallinarum (SG) is the fowl typhoid agent in chickens, a very severe disease with worldwide economic impact and with which mortality may reach up to $80 \%(5,9)$. It is one of a small group of serovars that typically produces typhoid-like infections in a narrow range of host species and which therefore represents a good model for human typhoid. The disease is most severe where environmental conditions and management systems do not allow hygienic control measures to be introduced (36). Although a live vaccine (SG9R strain) is commercially available and has been used extensively, it harbor undefined attenuations and retains a degree of virulence $(18,19,28,48)$. Despite of additional strains having been described of having more defined mutations $(5,7,8,22,56)$ none of these combine the high level of protection of the $9 \mathrm{R}$ strain with its ability to stimulate a specific circulating antibody (55). There thus remains considerable scope for further exploration of the virulence basis of this pathogen.

To survive intracellularly, SG uses anaerobic respiration to obtain its energy (20). As part of its ability to adapt to different growth conditions, SG may alter the composition of its respiratory system $(23,39)$. Different components can be substituted in the membrane in place of or in addition to other components as they are needed and can become fully functional parts of the entire system $(32,33)$. There are three types of respiratory components. (i) Substrate-specific dehydrogenases, which carry out the oxidation of organic substrates and feed electrons into the mobile quinone pool; (ii) quinones, which deliver reducing equivalents to the terminal oxidoreductases; and (iii) terminal oxidoreductases, which prevent the terminal electron acceptors from being used (17). The amount of each component is strictly regulated to optimize the respiratory chain according to the substrates present and the physiological needs of the cell (34) Bacteria can use substrates other than NADH, such as succinate, pyruvate, or lactate as primary electron donors and a number of alternative electron acceptors, such as dimethyl sulfoxide, fumarate, and nitrate, in addition to oxygen (17). Despite of the extensive understanding of bacterial electron transport and proton translocation, little is known about the relative contribution of the relevant proton-translocation enzymes to the growth and survival of pathogens in the host in either the gut or the intracellular environment.

Virtually all Salmonella isolates synthetize vitamin $\mathrm{B}_{12}$ (cobalamin or $\mathrm{CBL}$ ) de novo under anaerobic conditions alone. The synthesis can take place under aerobiosis only if the bacterium is provided by precursor substances such as cobinamide. $(13,24,27)$. The ability to synthesize and import $B_{12}$ requires more than 35 known genes (42). This means $1 \%$ of the microorganism genome (46), in addition to an extra $1 \%$ related to metabolic activity involving cobalamin. This large genetic investment in vitamin $B_{12}$ suggests that a $B_{12^{-}}$ dependent metabolism is important to natural populations of Salmonella (53). Mutations that eliminate $\mathrm{B}_{12}$ synthesis from otherwise wild-type strains cause no growth defect under the standard aerobic or anaerobic lab conditions used so far. The CBL biosynthetic operon of Salmonella Typhimurium is made up of 20 putative genes. These genes are organized in a single operon and can be separated into two groups: (i) genes involved in corrin ring synthesis, designated $c b i$ (the operon contains $17 c b i$ genes, $c b i \mathrm{~A}$ being the first) and (ii) genes involved in nucleotide loop assembly, designated cob (the operon contains three genes: $c o b \mathrm{U}, \operatorname{cobS}$ and $c o b \mathrm{~T})$ (37).

The biologically active forms of vitamin $\mathrm{B}_{12}$ are required in methylation, reduction and intramolecular rearrangements reactions $(13,47,54)$. A low redox potential generated during the anaerobic growth, increases expression of the $c o b$ 
operon 4 to 100 fold $(2,3,14)$.

Cobalamin is used as a cofactor in four known reactions in STM: (i) it is required by one methyltransferase (metH gene product) that catalyzes the last step in the methionine $\mathrm{B}_{12}$ dependent biosynthesis (43); (ii) it is required for the degradation of ethanolamine to acetaldehyde and ammonia providing both a carbon and a nitrogen source $(12,42)$; (iii) $\mathrm{B}_{12}$ is involved in the formation of the nonessential hypermodified Q base found in position 34 in the anticodon of RNAt ${ }^{\text {Asp,Asn,His,Tyr }}(16,35)$.

The main use of $\mathrm{B}_{12}$ in Salmonella appears to be a cofactor for propanediol dehydratase, the first enzyme in propanediol degradation. This conclusion is based on the fact that the $c o b$ operon, is induced by propanediol and is coregulated with the $p d u$ operon, which are encoding genes for propanediol degradation $(11,41)$. This control pattern suggests that perhaps propanediol could be used as a useful carbon and energy source which is frequently valuable and available under anaerobic conditions, because it is made as a by-product during degradation of common plant sugars (29, 53). Mutants blocked in $B_{12}$ synthesis show harmed anaerobic growth in carbon poor sources (38). The propanediol supports anaerobic growth when tetrathionate (not another acceptor) is used as an alternative electron acceptor $(38,53)$.

CbiA (Cobyrinic acid a,c-diamide sintetase) is the first glutamina aminotransferase in the anaerobic pathway of vitamin $B_{12}$ and catalyzes reactions in many sites of the substrate. CbiA is an indirect response by $c o b$ operon repression (40). CobS enzyme (Adenosylcobalamin-5'-P synthase) is bound to the cellular membrane and catalyzes the second to last step of the Ado-CBL production (30). The cobalamin biosynthesis is completely dependent on this enzyme $(1,31)$. The deletion of $c o b \mathrm{~S}$ and $c b i \mathrm{~A}$ genes prevent any form of cobalamin production (Adenosyl-, Cyano-,
Methyl-, Hidroxi-B ${ }_{12}$ ) under anaerobic conditions by Salmonella mutants (40). However, the exact relation is unknown.

Studies to understand the pathogenicity of Salmonella look for virulence genes. Although, the survival mechanisms are not considered to be virulent mechanisms, they are essential for the life of the bacterium. In this study, mutants of SG containing defective genes related to cobalamin biosynthesis were produced. Since SG is an intracellular parasite, the study might provide information about whether vitamin $\mathrm{B}_{12}$ biosynthesis could be essential to its survival in the host.

\section{MATERIAL AND METHODS}

Bacterial strain and culture media: Salmonella enterica serovar Gallinarum strain 9 produces typical systemic fowl typhoid with high mortality $(36,49)$. For ease of enumeration, spontaneous nalidixic acid-resistant $(25 \mu \mathrm{g} / \mathrm{mL})$ mutant derivates of this strain were used. The mutants were constructed from Salmonella Typhimurium F98 $\mathrm{Nal}^{\mathrm{r}}$ strain. The DNA homology was such as to permit using the same inactivated serovar Typhimurium sequences in serovar Gallinarum. The construction of the mutants, conjugation and transduction followed Sambrook \& Russel (44) and Turner et al. (51).

Broth cultures consisted of $10 \mathrm{~mL}$ volumes of LB broth (Invitrogen $\mathrm{N}^{\mathrm{o}} 12780-052$ ) incubated for $24 \mathrm{~h} / 37^{\circ} \mathrm{C}$ in a shaking incubator $(100 \mathrm{rpm})$. The broth culture contained approximately $1 \times 10^{8}\left(S\right.$. Gallinarum) and $1.2 \times 10^{9}(S$. Typhimurium) CFU/mL.

Mutant construction: Mutants were constructed in cobalamin biosynthesis deficiency. In brief, four primers were designed for each gene to be mutated, so that two 
Paiva, J.B. et al.

fragments close to the $5^{\prime}$ and $3^{\prime}$ ends of the gene could be amplified leaving a central deletion in the amplified gene and incorporating KpnI (Gibco 15232) or BamHI (Gibco 15201) sites facilitating the insertion of a kanamycin (cbiA gene) or spectinomycin (cobS gene) cassette. Initial cloning was carried out in pGEM T Easy vector (Promega L2001) and then in the pJCB12 suicide vector in E.coli S.17.1入 pir, which was used for conjugation into SG $9 \mathrm{Nal}^{\mathrm{r}}$. Mutants were selected based on their resistance to kanamycin or on streptomycin and ampicillin sensitivity and were checked for Salmonella O-antigens by slide agglutination with antisera and for smoothness by absence of agglutination with acriflavin $(0.001 \%)$. The integrity of the constructs was checked by PCR using the same primers (Figure 1).

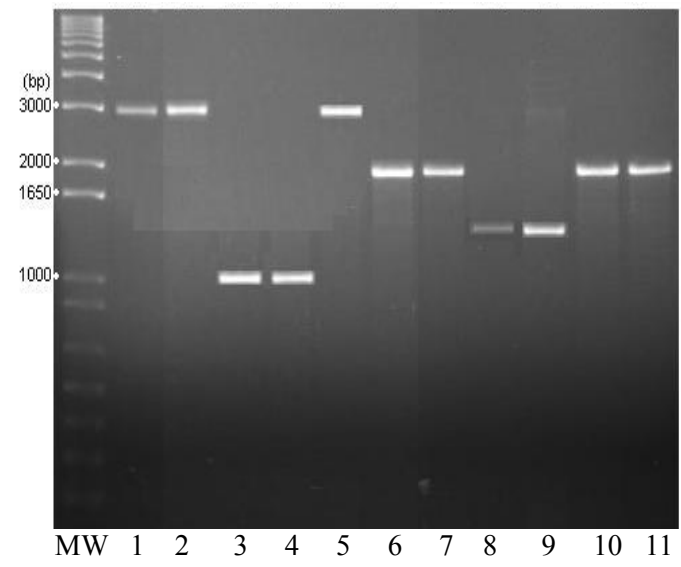

Figure 1: Agarose gel electrophoresis of the PCR products. DNA from isolated bacteria colonies. MW: molecular weight (1Kb plus DNA Ladder). Lanes 1-2: $\Delta c o b S \operatorname{Spec}^{\mathrm{r}}$ fragment from SG9Nal ${ }^{\mathrm{r}} \Delta c o b \mathrm{~S} \Delta c b i \mathrm{~A}$ (2964bp). Lanes 3-4: cobS fragment (wild) from SG9Nal ${ }^{\mathrm{r}}$ (994bp). Lane 5: Positive control with Salmonella Typhimurium F98 $\Delta c o b S$ Spec $^{\mathrm{r}}$ (2964bp) fragment. Lanes 6-7: $\Delta c b i \mathrm{~A} \mathrm{Kan}{ }^{\mathrm{r}}$ fragment from $\mathrm{SG} \mathrm{Nal}^{\mathrm{r}} \Delta \operatorname{cobS} \Delta c b i \mathrm{~A}^{-}$(1930bp). Lanes 8-9: cbiA fragment from wild SG9Nal ${ }^{\mathrm{r}}$ (1360bp). Lanes 10-11: Positive control with Salmonella Typhimurium F98 $\Delta c b i \mathrm{~A} \mathrm{Kan}^{\mathrm{r}}(1930 \mathrm{pb})$.
Primers designed:

cobS:

Primer 1: gagatctagaacgaatctgctgtttgcget

Primer 2:cagcagggtacctagcggaataccacaccag

Primer 3: ccgctaggtaccetgctgaccggtggttttca

Primer 4: tctagaacagacccagcagaaagatc

cbiA:

Primer 1: catctagaaaggcatcacgcatttattc

Primer 2: ccgtaaggtaccaatggcatttttgaggagct

Primer 3: gccattggtaccatacggtgatgttaaaacat

Primer 4: tgtctagacagccagtgctgcaacattt

Transduction: Mutants of SG with double deletions were obtained by transduction using bacteriophage P22 following standard protocols $(4,44)$. Transductants were plated on LB agar (Invitrogen $\mathrm{N}^{\mathrm{o}}$ 22700-025) containing spectinomycin or kanamycin and after incubation at $37 \mathrm{C} / 24 \mathrm{~h}$ were again checked by PCR.

\section{Virulence assays}

Experiment 1. Assessment of mortality: Virulence was assessed by oral inoculation of groups of five-day-old brown commercial layers with $0.5 \mathrm{~mL}$ of either an undiluted culture containing $10^{8} \mathrm{CFU} / \mathrm{mL}$ or diluted at $10^{-2}$ to contain $10^{6}$ $\mathrm{CFU} / \mathrm{mL}$ of mutant and wild cultures of Salmonella Gallinarum. This variety of commercial brown chickens was chosen because it is susceptible to clinical fowl typhoid (9, 15). Mortality was recorded over a period of 28 days. Data were assessed by Qui-square test $(\mathrm{p}<0.05)(21)$.

Experiment 2. Assessment of systemic infection: The systemic infection was assessed by oral inoculation of groups of five-day-old brown commercial layers with $0.5 \mathrm{~mL}$ of the mutant or wild culture containing $10^{8} \mathrm{CFU} / \mathrm{mL}$. The bacteriological analysis was carried out as described by 
Barrow \& Lovell (6) with some modification. At 2, 5, 7, 14, 21 and 28 days post-inoculation (dpi), samples from the spleen and liver were collected and diluted (1:10) in phosphate-buffered saline, $\mathrm{pH} 7.4$ (PBS). The organ samples were macerated in a pestle and mortar. The viable count of $\mathrm{SGNal}^{\mathrm{r}} \Delta \operatorname{cobS} \Delta c b i \mathrm{~A}$ and $\mathrm{SGNal}^{\mathrm{r}}$ in the samples were estimated by plating aliquots of decimal dilutions on BGA $\mathrm{Nal} / \mathrm{Nov}$ incubated overnight at $37^{\circ} \mathrm{C}$. The first dilution of the sample was added to an equal volume of double-concentrated $\mathrm{SN}$. This was incubated at $37^{\circ} \mathrm{C}$ overnight and plated on BGANal/Nov agar plate when there was no growth from the viable count. Data of viable counts were transformed logarithmically $\left(\log _{10}\right)$ and subjected to analysis of variance. Media were compared statistically by Tukey test $(\mathrm{p}<0.05)$.

\section{RESULTS}

In experiment 1 , the mortality caused by SG $\Delta c o b \mathrm{~S}$ or/and $\Delta c b i \mathrm{~A}$ genes was assessed (Table 1). In groups where the birds were challenged with neat culture of the strains containing single mutation, the mortality was similar to group of birds receiving the wild strain of $\mathrm{SGNal}^{\mathrm{r}}$, and there was no mortality in birds inoculated with $\mathrm{SG} \mathrm{Nal}^{\mathrm{r}} \Delta \operatorname{cobS} \Delta c b i \mathrm{~A}$ $(\mathrm{p}<0.05)$. At lower dose, however, SG $\Delta c o b \mathrm{~S}$ and $\mathrm{SG} \Delta c b i \mathrm{~A}$ provoked mortality higher than $\mathrm{SGNal}^{\mathrm{r}}(\mathrm{p}<0.05)$.

Figure 2 shows the results on the presence of $\mathrm{SG} \mathrm{Nal}{ }^{\mathrm{r}}$ $\Delta c o b \mathrm{~S} \Delta c b i \mathrm{~A}$ in the liver and spleen of birds over a period of 28 days post-infection (dpi) in comparison with the infection of birds by the wild SG strain. Five birds in each group were inspected at 2, 5, 7, 14, 21 and 28 dpi. There was always a smaller quantity of the $\mathrm{SG} \mathrm{Nal}{ }^{\mathrm{r}} \Delta \operatorname{cobS} \Delta c b i \mathrm{~A}$ strain in the liver and spleen than there was of the $\mathrm{SGNal}^{\mathrm{r}}$ strain $(\mathrm{p}<0.05)$. Mortality by SGNal ${ }^{\mathrm{r}}$ strain started around seven dpi and all of remaining birds died before 14dpi whereas no mortality was seen in group of birds infected with $\mathrm{SG} \mathrm{Nal}{ }^{\mathrm{r}} \Delta \operatorname{cobS} \Delta c b i \mathrm{~A}$.

\section{DISCUSSION AND CONCLUSION}

Fowl typhoid is a systemic disease in chickens caused by Salmonella Gallinarum, an intracellular anaerobic facultative parasite. It is a very severe disease and during its course, the bacterium persists intracellularly. The virulence factors are responsible for the development and evolution of the illness (52). The bacterium also uses other resources to survive intracellularly. To breathe anaerobically, Salmonella produces enzymatic complexes according to the available substrate in the host cell. Sometimes, under certain circumstances, enzymatic complexes could inhibit each other's action.

In the present work, mutants of SG containing defective genes related to cobalamin biosynthesis were prepared. These mutants were inoculated orally in 5-day-old chickens susceptible to clinical fowl typhoid. For $\mathrm{SGNal}^{\mathrm{r}} \Delta \operatorname{cobS}$ and $\mathrm{SGNal}^{\mathrm{r}} \Delta c b i \mathrm{~A}$, the lower dose provoked higher mortality in comparison to the wild strain $(\mathrm{p}<0.05)$, while there was no mortality in groups of birds inoculated with the strain with double mutation $\left(\mathrm{SGNal}^{\mathrm{r}} \Delta c b i \mathrm{~A} \Delta \operatorname{cobS}\right)$. These results were similar to findings of Sampson \& Gotschlich (45) that discussed the possibility of the Salmonella Typhimurium cobmutant strain being more virulent than the wild strain in mice. Sampson \& Gotschlich (45) suggested that the inability to produce vitamin $\mathrm{B}_{12}$ might be the factor, which is responsible for increasing its virulence. However, the strain of SG containing double defective genes, cbiA and $c o b \mathrm{~S}$, was completely attenuated, provoking no mortality. There is also the fact that the bird's life span is shorter than that of the wild strain of SG. There is no explanation why the single mutation in $c b i \mathrm{~A}$ and $c o b \mathrm{~S}$ genes might increase the virulence and why the double mutant loses it. The explanation given by Sampson \& Gotschlich (45) cannot be accepted since works carried out later demonstrated that the wild STM strain used 
Paiva, J.B. et al.

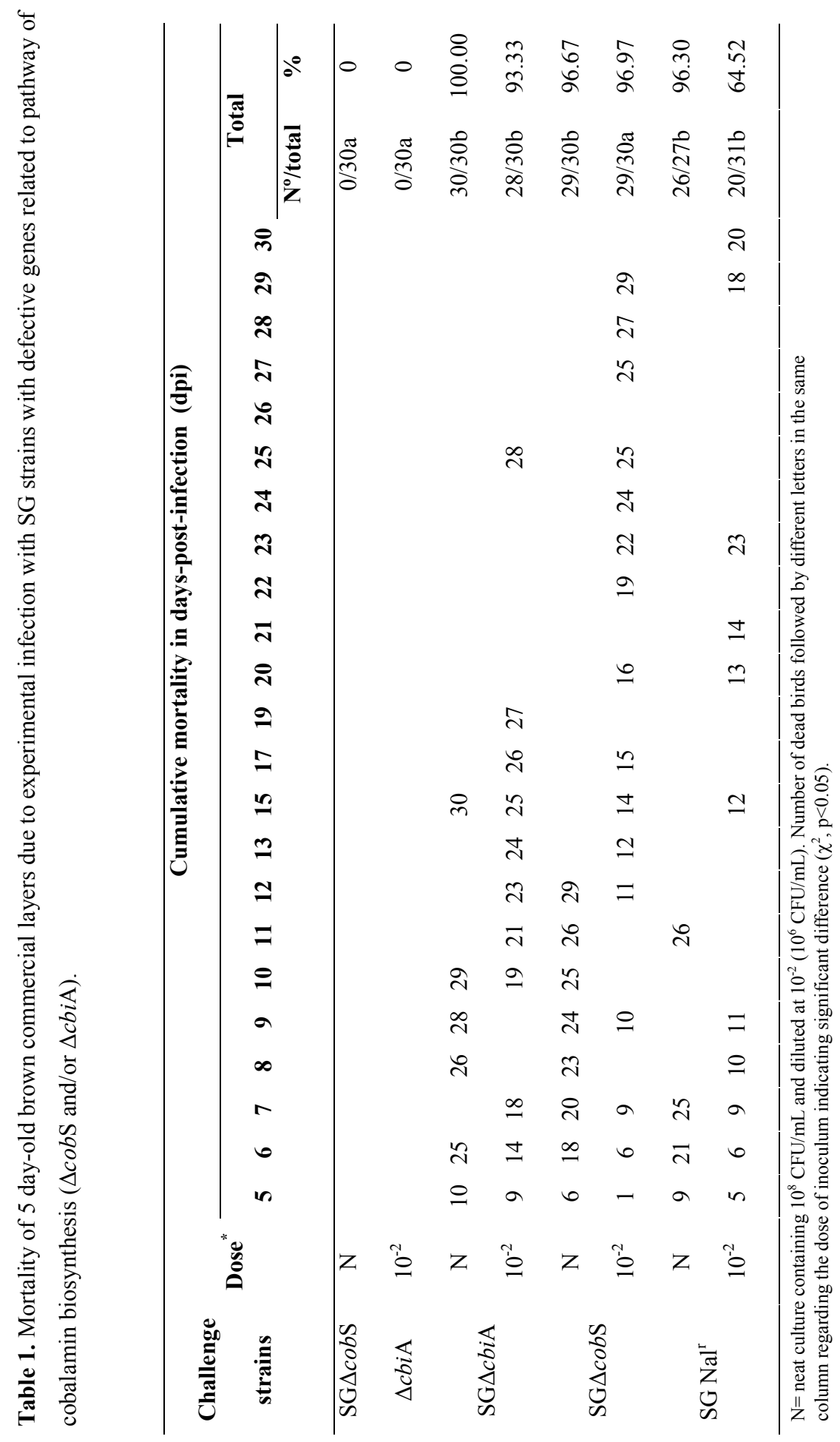



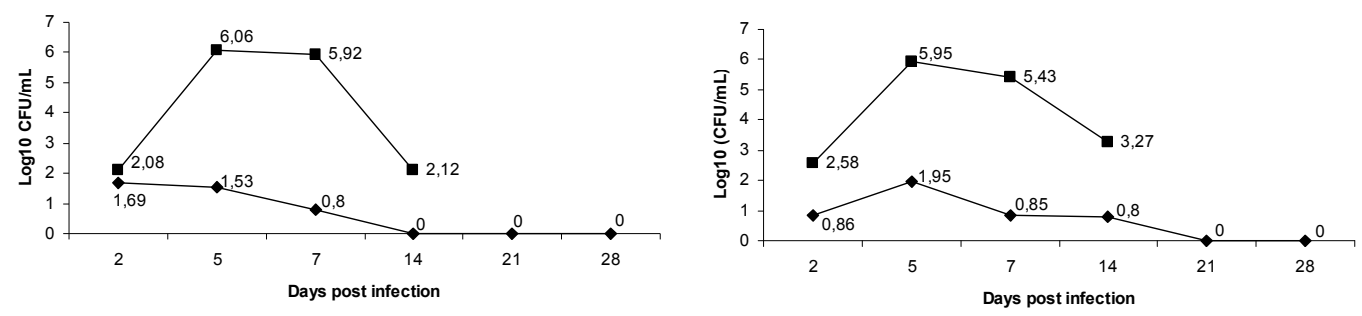

Figure 2. Media of the viable number $\left(\log _{10} \mathrm{CFU} / \mathrm{mL}\right)$ of Salmonella Gallinarum $\mathrm{Nal}^{\mathrm{r}} \Delta \operatorname{cobS} \Delta c b i \mathrm{~A}(\diamond)$ and $S$. Gallinarum Nal (घ) in the liver and spleen of five brown commercial layers experimentally infected at 5 days old. In group infected with $S$. Gallinarum $\mathrm{Nal}^{\mathrm{r}}$ the remaining birds died before $21 \mathrm{dpi}$.

for comparison with cobS mutant was naturally attenuated (10).

According to Jeter et al. (24), Salmonella Typhimurium may be unable to synthesize cobalamin for three reasons: (i) the phenotipically defective strain in branch I (cob) synthesizes cobalamin only when cobinamide is supplied; (ii) - the defective strain in branch II (cob) synthesizes cobalamin only when dimethylbenzimidazole (DMB) is supplied; and (iii) - the defective strain in branch III (cob) fails to make cobalamin even when provided with both precursors (cobinamide or DMB). Therefore, the $\mathrm{SGNal}^{\mathrm{r}} \Delta \operatorname{cobS}$ strain which has altered branch III, and $\mathrm{SGNal}^{\mathrm{r}} \Delta c b i \mathrm{~A}$ which has altered branch I should be incapable of synthesizing cobalamin (vitamin $\mathrm{B}_{12}$ ). However, in this study, single mutation exacerbated the virulence of SG, and only when the bacterium was defective in two genes did the strain become attenuated. Hence, it is not possible to understand the role that cobalamin plays in the virulence of the bacterium. Perhaps, when the mutant has a single alteration, additional pathway takes place in the bacterium while the double alteration cannot be overcome. According to Roth et al. (43), the cbiA gene is located in part I of the $c o b$ operon and it is the first place to start the transcription for the biosynthesis of cobalamin in $S$. Typhimurium, which codifies an amidase that acts later in the biosynthesis via. Thus, the double mutant has defective genes that act in branch I (cbiA) and branch III (cobS).

It is possible that vitamin $B_{12}$ within the bacterium is capable of regulating a gene or a group of genes which directly or indirectly control any virulence factor. Another possibility is that somehow it was sensed by the host. This detection might conceivably cause an altered response by the host resulting in less virulent infection.

Huang et al. (23) showed that cob operon expression is induced during the infection of pigs by STM, where according to them possible environmental signals exist specifically in the lymphoid tissues that induce the cob operon, either as a life requirement in this tissue itself or as a prelude to passage into the intestinal tract. Previous work has shown that the invasion of epithelial cells by Salmonella is co-regulated with propenodiol and ethanolamine catabolism including $c o b$ expression $(25,26)$. It is possible that environmental cues encountered by Salmonella are regulated by both metabolic and virulent functions in the host.

The results obtained showed that the singular deletion in $c b i \mathrm{~A}$ or $c o b \mathrm{~S}$ genes did not interfere in the life of SG in the host, perhaps because single deletion is not enough to impede 
Paiva, J.B. et al.

vitamin $B_{12}$ biosynthesis. It was noticed that diluted $S G$ mutants with single deletion produced higher mortality than the wild strain of SG did. When double mutation was carried out, the mutant of SG was unable to provoke mortality in susceptible chickens. Further work towards bacterium physiology should be carried out to elucidate the events described in this research.

\section{ACKNOWLEDGEMENT}

The authors were thankful to FAPESP and CNPq by financial supports.

\section{RESUMO}

\section{Mutante de Salmonella enterica serovar Gallinarum}

\section{duplo defectivo na biossíntese de cobalamina é avirulento} para aves.

Salmonella enterica serovar Gallinarum (SG) é o agente do tifo aviário, doença severa que provoca mortalidade em até $80 \%$ do plantel de aves. SG encontra-se entre os poucos sorotipos de Salmonella que são agentes etiológicos de enfermidade específica, à semelhança de Salmonella Typhi em seres humanos podendo, portanto, servir de modelo experimental para outras salmoneloses hospedeiro especíifcas. Além dos mecanismos de virulência, a bactéria utiliza mecanismos de sobrevivência para permanecer no hospedeiro. A ativação desses mecanismos pode ou não estar associada à ativação dos mecanismos de virulência. Entre os mecanismos fisiológicos, está a produção de vitamina $B_{12}$ que Salmonella spp. realiza em ambientes anaeróbicos, como quando encontra-se intracelularmente no organismo hospedeiro. Neste estudo, analisou-se a infecção de aves por cepas de SG, que tiveram genes alterados que participam da biossíntese de vitamina $\mathrm{B}_{12}$. Foram produzidos mutantes de $\mathrm{SG}$ contendo os genes $c b i \mathrm{~A}$ e $c o b \mathrm{~S}$ alterados e um terceiro, contendo ambos os genes alterados. A sobrevivência e a ação patogênica de SG não foi modificada pela alteração simples de um dos genes, mas tornou a cepa de SG completamente atenuada quando os dois foram modificados. A mortalidade provocada pela cepa selvagem de SG foi de 64,52\%, enquanto que não observou-se mortalidade alguma no grupo de aves infectadas com $\mathrm{SGNal}^{\mathrm{r}} \Delta \operatorname{cobs} \Delta c b i \mathrm{~A}$. Estudos futuros deverão ser realizados para elucidar este processo fisiológico bacteriano e para avaliar a utilização desta cepa de SG como cepa vacinal.

Palavras-chaves: Salmonella Gallinarum, cobalamina, mutantes de Salmonella, atenuação de genes, cbiA, cobS.

\section{REFERENCES}

1. Anderson, P.J.; Lango, J.; Carkeet, C.; Britten, A.; Kräutler, B.; Hammock, B.D.; Roth, J.R. (2008). One pathway can incorporate either adenine or dimethylbenzimidazole as an alpha-axial ligand of B12 cofactors in Salmonella enterica. J. Bacteriol. 190 (4), 1160-1171.

2. Andersson, D.I.; Roth J.R. (1989a). Mutations affecting regulation of cobinamide biosynthesis in Salmonella typhimurium. J. Bacteriol. 171 (12), 6726-6733

3. Andersson, D.I.; Roth, J.R. (1989b). Redox regulation of the genes for cobinamide biosynthesis in Salmonella typhimurium. J. Bacteriol. 171 (12), 6734-6739.

4. Barrow, P.A.; Hassan, J.O.; Berchieri Jr, A. (1990). Reduction in faeca excretion by chickens of Salmonella typhimurium by immunization with avirulent mutants of S. typhimurium. Epidemiol. Infect. 104 (3), 413-426.

5. Barrow, P.A. (1990). Immunity to experimental fowl typhoid in chickens induced by a virulence plasmid-cured derivative of Salmonella gallinarum. Infect. Immun. 58 (7), 2283-2288. 
6. Barrow, P.A.; Lovell, M.A. (1991). Experimental infection of egglaying hens with Salmonella enteritidis phage type 4. Avian Pathol. 20 (2), 335-348

7. Barrow, P.A.; Lovell, M.A.; Old, D.C. (1992). In vitro and in-vivo characteristics of TnphoA mutant strains of Salmonella serotype Gallinarum not invasive for tissue culture cells. J. Med. Microbiol. 36, 389-397.

8. Barrow, P.A.; Lovell, M.A.; Stocker, B.A.D. (2000). Protection against experimental fowl typhoid by parenteral admininstration of live SL5928, an aroA-serC (aromatic dependent) mutant of a wild-type Salmonella Gallinarum strain made lysogenic for P22sie. Avian Pathol. 29 (5), 423-431.

9. Berchieri Jr, A.; Oliveira, G.H.; Pinheiro, L.A.P.; Barrow, P.A. (2000). Experimental Salmonella Gallinarum infection in light laying hens lines. Braz. J. Microbiol. 31 (1), 50-52.

10. Björkman, J.; Rhen, M.; Anderson, D.I. (1996). Salmonella Typhimurium cob mutants are not hyper-virulent. FEMS Microbiol. Lett. 139 (2), 121-126.

11. Bobik, T.A.; Ailion, M.; Roth, J.R. (1992). A single regulatory gene integrates control of vitamin B12 synthesis and propanediol degradation. J. Bacteriol. 174 (7), 2253-2266.

12. Chang, G.W.; Chang, J.T. (1975). Evidence for the B12-dependent enzyme ethanolamine deaminase in Salmonella. Nature. 254, 150-151.

13. Escalante-Semerena, J.C. (2007). Conversion of cobinamide into adenosylcobamide in bacteria and archaea. J. Bacteriol. 189 (13), 455460 .

14. Escalante-Semerena, J.C.; Roth, J.R. (1987). Regulation of cobalamin biosynthetic operons in Salmonella typhimurium. J. Bacteriol. 169 (5), 2251-2258.

15. Freitas, O. C.; Arroyave, W.; Alessi, A. C.; Fagliari, J.J.; Berchieri Jr, A. (2007). Infection of commercial laying hens with Salmonella Gallinarum: Clinical, anatomopathological and haematological studies. Braz. J. Poultry Sci. 9 (2), 133-141.

16. Frey, B.; Mc-Closkev, J.; Kersten, J.; Wkersten, H. (1988). New function of vitamin B12: cobamide-dependent reduction of epoxyqueuosine to queuosine in tRNAs of Escherichia coli and Salmonella typhimurium. J. Bacteriol. 170 (5), 2078-2082.

17. Gennis, R.B.; Stwart, V. (1996). Respiration. In: Neidhardt, F.C.; Curtiss III R.; Ingraham, J.L.; Lin, E.C.C.; Low K.B.; Maganasik, B.; Reznikoff, W.S.; Riley, M.; Schaechter, M.; Umbarger, H.E. (eds). Escherichia coli and Salmonella: Cellular and molecular biology. American Society for Microbiology, Washington D.C., USA, p. 217 261.
18. Gordon, W.A.M.; Luke, D. (1959). A note on the use of the 9R fowl typhoid vaccine in poultry breeding flocks. Vet. Rec. 71 (44), 926-927.

19. Gordon, R.F.; Garside, J.S.; Tucker, J.F. (1959). A note on the use of living attenuated vaccines in the control of fowl typhoid. Vet. Rec. 71 (44), 300-305.

20. Gottschalk, G. (1986). Bacterial Metabolism. In: Springer-Veralg, New York, 359p.

21. Greenwood, P.S.; Nikulin, M.S. (1996). In: WILEY, J. (Ed). A Guide to Chi-Squared Testing. New York, p. 280,

22. Griffin, H.G.; Barrow, P.A. (1993). Construction of an aroA mutant of Salmonella serotype Gallinarum: its effectiveness in immunization against experimental fowl typhoid. Vaccine. 11 (4), 457-462.

23. Huang, Y.; Leming, C.L.; Suyemoto, M.; Altier, C. (2007). Genomewide screen of Salmonella genes expressed during infection in pigs, using in vivo expression technology. Appl. Environ. Microbiol. 73 (23), 7522-7530.

24. Jeter, R.; Oliveira, B.M.; Roth, J.R. (1984). Salmonella typhimurium synthesizes cobalamin (vitamin $\mathrm{B}_{12}$ ) de novo under anaerobic growth conditions. J. Bacteriol. 159 (1), 206-216.

25. Lawhon, S.D.; Frye, J.G.; Suyemoto, M.; Porwollik, S.; Mcclelland, M.; Altier, C. (2003). Global regulation by CsrA in Salmonella typhimurium. Mol. Microbiol. 48 (6), 1633-1645.

26. Lawhon, S.D.; Maurer, R.; Suyemoto, M.; Altier, C. (2002). Intestina short-chain fatty acids alter Salmonella Typhimurium invasion gene expression and virulence through BarA/SirA. Mol. Microbiol. 46 (5) 1451-1464

27. Lawrence, J.G.; Roth, J.R. (1995). The cobalamin (coenzyme B12) biosynthetic genes of Escherichia coli, J. Bacteriol. 177 (22), 63716380.

28. Lee, Y.J.; Mo, I.P.; Kang, M.S. (2005). Safety and efficacy of Salmonella gallinarum 9R vaccine in young laying chickens. Avian Pathol. 34 (4), 362-366.

29. Lin, E.C.C. (1987). Dissimilatory pathways for sugars, polyols, and carboxy-lates, In: F.D. Neidhardt, J.L. Ingraham, K.B. Low, B. Magasanik, M. Schaechter \& H.E. Umbarger. Escherichia coli and Salmonella Typhimurium: cellular and molecular biology. American Society for Microbiology, Washington, USA, p. 244-284.

30. Maggio-Hall, L.A., Claas, K.R.; Escalante-Semerena, J.C. (2004). The last step in coenzyme $\mathrm{B}_{12}$ synthesis is localized to the cell membrane in bacteria and archaea. Microbiology. 150 (5), 1385-1395.

31. Maggio-Hall, L.A.; Escalante-Semerena, J.C. (1999). In vitro synthesis of the nucleotide loop of adenosylcobalamin by Salmonella Typhimurium enzymes. Proc. Nat. Acad. Sci. 96 (21), 11798-11803. 
Paiva, J.B. et al.

32. Mahan, M.J.; Slauch, J.M.; Mekalanos, J.J. (1993). Selection of bacterial virulence genes that are specifically induced in host tissues. Sci, 259, 686-688.

33. Mekalanos, J.J. (1992) Enviromental signals controlling expression of virulence determinats in bacteria. J. Bacteriol. 174 (1), 1-7.

34. Moreno-Vivián, C.; Cabello, P.; Martínez-Luque, M.; Blasco, R.; Castillo, F. (1999). Prokaryotic nitrate reduction: molecular properties and functional distinction among bacterial nitrate reductases. $J$. Bacteriol. 181 (21), 6573-6584.

35. Noguchi, S.; Nishimura, Y.; Hirota, Y.; Nishimura, S. (1982). Isolation and characterization of an Escherichia coli mutant lacking tRNAguanine transglycosylase. Function and biosynthesis of queuosine in tRNA. J. Biol. Chem. 257 (11), 6544-6550.

36. Oliveira, G.H.; Fernandes, A.C.; Berchieri Jr, A. (2005). Experimental infection of laying hens with Salmonella enterica serovar Gallinarum. Braz. J. Microbiol. 36 (1), 51-56.

37. O’Toole, G.A.; Rondon, M.R.; Trzebiatowski, J.R.; Suh, S.; EscalanteSemerena, J.C. (1996). Biosynthesis and utilization of adenosylcobalamin (coenzyme B12). In F. C. Neidhardt, R. Curtiss III, J. L. Ingraham, E. C. C. Lin, K. B. Low, B. Magasanik, W. S. Reznikoff, M. Riley, M. Schaechter, H. E. Umbarger. (eds). Escherichia coli and Salmonella: cellular and molecular biology. ASM Press, Washington, USA, p.710-720.

38. Price-Carter, M.; Tingey, J.; Bobik, T.A.; Roth, JR. (2001). The alternative electron acceptor tetrathionate support $\mathrm{B}_{12}$-dependent anaerobic growth of Salmonella enterica serovar Typhimurium on ethanolamine or 1,2-propanediol. J. Bacteriol. 183 (8), 2463-2475.

39. Richardson, D.J. (2000). Bacterial respiration: a flexible process for a changing environment. Microbiology, 146 (2000), 551-571.

40. Richter-Dahlfors, A.A.; Ravnum, S. ; Andersson, D.I. (1994). Vitamin B12 repression of the cob operon in Salmonella Typhimurium: translational control of the cbiA gene. Mol. Microbiol. 13 (3), 541-553.

41. Rondon, M.R.; Escalante-Semerena, J.C. (1992). The poc locus is required for 1,2-propanediol-dependent transcription of the cobalamin biosynthetic (cob) and propanediol utilization (pdu) genes of Salmonella typhimurium. J. Bacteriol. 174 (7), 2267-2272.

42. Roof, D.M.; Roth, J.R. (1988). Ethanolamine utilization in Salmonella typhimurium. J. Bacteriol. 170 (9), 3855-3863.

43. Roth, J.R.; Lawrence, J.G.; Rubenfield, M.; Kieffer-Higgins, S.; Church, G.M. (1993). Characterization of cobalamin (vitamin $\mathrm{B}_{12}$ ) biosynthetic genes of Salmonella typhimurium. J. Bacteriol. 175 (11),
3303-3316.

44. Sambrook, J.; Russel, D.W. (2001). Molecular cloning. A laboratory manual. Cold Spring Harbor Laboratory Press.

45. Sampson, B.; Gotschlich, E.C. (1992). Elimination of the vitamin B B $_{12}$ uptake or synthesis pathway does not diminish the virulence of Escherichia coli $\mathrm{K} 1$ of Salmonella typhimurium in three model systems. Infect. Immun. 60 (9), 3518-3522.

46. Schmeiger, H. (1971). A method for detection of phage mutants with altered transducing ability. Mol. Gen. Genet. 110 (4), 378-381.

47. Schneider, Z.; StroinÄski, A. (1987). Methylcobamide-dependent reactions. In: Z. Schneider, A. StroinÄski. (1987). Comprehensive B12 Chemisty, Biochemistry, Nutrition, Ecology, Medicine. De Gruyter, p. 259-266.

48. Silva, E.N.; Snoeyenbos, G.H.; Weinack, O.M.; Smyser, C.F. (1981). Studies on the use of the 9R strain of Salmonella Gallinarum as a vaccine in chickens. Avian Dis. 25 (1), 38-52.

49. Smith, H.W. (1955). Observations on experimental fowl typhoid. J. Comp. Pathol. 65 (1), 37-54.

50. Smith, H.W.; Tucker, J.F. (1980). The virulence of Salmonella for chickens; their excretion by infected chickens. J. Hyg. 84 (3), 479-488.

51. Turner, A.K.; Zhang-Barber, L.; Wigley, P.; Muhammad, S.; Jones, M.A.; Lovell, M.A.; Hulme, S.; Barrow, P.A. (2003). Contribution of proton-translocating proteins to virulence of Salmonella enterica serovars Typhimurim, Gallinarum and Dublin chickens and mice. Infect. Immun. 71 (6), 3392-3401.

52. Van Immerseel, F.; Methner, U.; Rychlik, I.; Nagy, B.; Velge, P.; Martin, G.; Foster, N.; Ducatelle, R.; Barrow, P.A. (2005). Vaccination and early protection against non-host-specific Salmonella serotypes in poultry: exploitation of innate immunity and microbial activity. Epidemiol. Infect. 133 (6), 959-978.

53. Walter, D.; Ailion, M.; Roth, J.R. (1997). Genetic characterization of the pdu operon: use of 1,2-propanediol in Salmonella Typhimurium. $J$. Bacteriol. 179 (4), 1013-1022.

54. Warren, M.J.; Raux, E.; Schubert, H.L.; Escalante-Semerena, J.C (2002). The biosynthesis of adenosylcobalamin (vitamin B12). Nat Prod. Rep. 19 (4), 390-412.

55. Zhang-Barber, L.; Turner, A.K.; Barrow, P.A. (1999). Vaccination for control of Salmonella in poultry. Vaccine 17 (20), 2538-2545.

56. Zhang-Barber, L.; Turner, A.K.; Dougan, G.; Barrow, P.A. (1998). Protection of chickens against experimental fowl typhoid using a nuoG mutant of Salmonella serotype Gallinarum. Vaccine. 16 (9), 899-903. 